\title{
MICROSOFT ACQUIRED NOKIA IN UNIPOLAR OPERATING
} SYSTEM MARKET

Netra Pal Singh Management Development Institute, India

E-mail: knpsingh@mdi.ac.in

Submission: $13 / 11 / 2013$

Revision: 05/01/2014

Accept: 10/01/2014

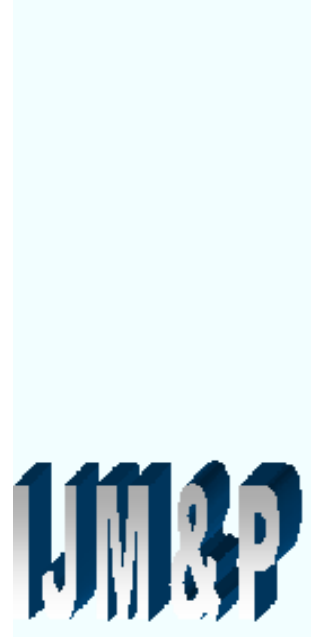

\section{ABSTRACT}

The recent big tickets include Microsoft acquiring part of Nokia for US\$ 7.2 billion, Verizon buy $45 \%$ stake in Vodafone for US $\$ 130$ billion, Google acquiring Motorola for 12.5 billion. These buyouts are analyzed and commented by experts of the industry. This research paper attempted to collate their view in the context of Microsoft and Nokia deal on six parameters. These parameters are (i) reasons for the downfall of the Nokia market share, (ii) general comments of the experts, (iii) similarities / dissimilarities of past and business models of the smartphone business, (iv) reasons for Microsoft to buy out Nokia, (vi) impact of buyout on Microsoft, Nokia, consumers and markets. In addition, paper discusses the existing theories of merger \& acquisition in telecom sector in the past.

Keyword: Smartphone, Microsoft, Nokia, HERE Maps, Galaxy, Lumia, Synergy Trap Hypothesis. 


\section{INTRODUCTION}

According to Redmond (2013), Microsoft will pay EUR 3.79 billion to purchase substantially all of Nokia's Devices \& Services business, and EUR 1.65 billion to license Nokia's patents, for a total transaction price of EUR 5.44 billion in cash. Microsoft will draw upon its overseas cash resources to fund the transaction. The transaction is expected to close in the first quarter of 2014, subject to approval by Nokia's shareholders, regulatory approvals and other closing conditions. Microsoft CEO Steven Ballmer told reporters at Nokia's headquarters in Finland, "It's a signature event".

Walton (2013) and other experts commented on Microsoft-CEO statement in the context of buying Nokia. They said his justification is based on four factors. These are (i) acceleration of phone share; CEO Microsoft quoted the success of Lumia in the context, (ii) strengthens overall opportunity; CEO Microsoft mentioned that Windows Phone will improve the health of the entire Windows ecosystem. Microsoft believes that the traditional role of Windows in enterprise software will help elevate Windows Phone into the workplace as well as in the home segment what it called the "consumerization of IT". Microsoft believed that increased smartphone sales will lead to increased tablet sales and increased tablet sales will lead to increased PC sales. It will help Microsoft to recreate every Google and Apple service for Windows Phone, (iii) smart acquisition; CEO Microsoft mentioned that the purchase used offshore cash so as not to have any impact on investors. Nokia purchase will help company's Windows Phone business to achieve breakeven of 50 million devices faster, (iv) strong execution plan; he mentioned that Nokia will continue operating as it is with minimal interference coming from the merger. The Nokia executive team will join Microsoft, but actual phone development will continue unabated in Finland.

Further to it, Microsoft believes that there is an urgent need of having a mobile handset device business, if Microsoft wishes to compete with Google and Apple. However, the experts and the market have different views on the buyout. Sizable segment of the market does not report it a best buyout for Microsoft.

In any case, the success and failure of the Microsoft and Nokia deal will have huge impact on the phone business across the globe. Keeping in view the 
importance of such deal in mobile phone market, this research is attempted with two objectives.

Objective 1: To present an analysis of the very recent views expressed by experts and members of eco-systems of mobile communication industry. These views are mainly with respect to impact on eco-systems of mobile industry, acquirer Microsoft and bought out company Nokia.

Objective 2: To established similarities with earlier theories/findings of merger and acquisition of telecom sector such as synergy trap hypothesis (MYEONG-CHEOL, et al. 2002), asset efficiency hypotheses (SALLEH, et al. 2013; BARKEMA; SCHIJVEN, 2008), hypothesis with respect to innovative performance of the acquiring firm and similarities in knowledge base of acquired firm (CLOODT, et al. 2006), and ethical conduct of mergers and acquisition have relations with job performance (LIN; WEI, 2006).

\section{METHODOLOGY}

The methodology adopted in this research work is exploratory cum descriptive in nature. The methodology of the study is designed keeping in view above two objectives of the study. Most of the data used in the study is secondary data collected from the articles, news reports, press releases published on the web before and after the buyout of Nokia phone business by Microsoft. These sources are very recent. The analysis is similar to content analysis. Key words and phrases were identified from the secondary sources with respect to (i) reasons for downfall of Nokia, (ii) general views on the deal in the market, (iii) similarities \& dissimilarities of the past \& business models in relation to merger \& acquisition activities of competitors in the market, (iv) specific reasons for Microsoft to buy Nokia, (v) impact on the stakeholders.

In addition, analysis of the Microsoft-Nokia deal is done with the following earlier theories/ researches of the past with respect to telecom company's merger and acquisition.

(i) Synergy Trap Hypothesis: It says that immediately before and after an acquisition announcement, the acquiring firm's stock price is negatively 
affected and the target firm's stock price is positively affected. (MYEONGCHEOL, et al. 2002).

(ii) Technical Efficiency: Merger \& Acquisition (M\&A) activities are one of the routes to enhance relative technical efficiency in an effort to increase the overall efficiency which would later be translated into increase revenue. (SALLEH, et al. 2013); BARKEMA; SCHIJVEN, 2008).

(iii) Innovative performance: Non-technological M\&As appear to have a negative impact on the acquiring firm's post-M\&A innovative performance. With respect to technological M\&As, a large relative size of the acquired knowledge base reduces the innovative performance of the acquiring firm (CLOODT et al. 2006).

(iv) Ethical conduct: Ethical conduct in M\&A is significantly correlated with employee job performance (LIN; WEI, 2006).

It is difficult to prove all such theories at this stage since empirical evidences for some hypotheses are not yet available at present. But it was possible to have data collected with respect to first and fourth hypotheses from the sources as listed above.

The data with respect to recent statistics of top smartphone operating systems (OS), shipments, and market share from 2008 to 2013, world wide mobile terminal sales to end users from 2009 to 2013 , smart phone OS Shares in select countries for July 2012 \& 2013 with a view to see the dominance of operating system providers and handset manufacturers.

In addition, data with respect to market share forecast of Operating System in India for 2017, and market share of feature phones and smart phones in India for the year 2Q 2011, 2Q 2012, 2Q 2013 was also collected to have an idea how the dynamics of a big market is behaving. The data is given in Table A1 to Table A6.

\section{REASONS OF DOWNFALL OF NOKIA}

This section present reasons for the downfall of the Nokia. Analysis is based on mainly expert opinion of Murtazin (2010), Thompson (2013), Gassée (2012), Ciol (2012), Chang (2012), Ahonen (2013), Edwards (2013), Rox (2012), Lobo (2011), Fundey.com (2012), and Dominies Communicate (2013). 
(i) Operating System \& Apps: During August, Thompson (2013) wrote that both BlackBerry and Nokia had significant strengths in this stack:

"BlackBerry had differentiated hardware - there are people who still swear by their keyboards - and highly differentiated services, including BlackBerry Enterprise Server and BlackBerry Messenger"

"Nokia dominated all the parts of this stack you don't see: they had, and in some respect, still have, the best supply chain and distribution network. In addition, they had high quality hardware that served every segment imaginable"

However, these strengths were missing in operating system \& apps for success and compete. Ciol (2013) reported that operating system space was nearly occupied by Android and iOS and Window operating system does not have much role.

(ii) Domination Blindness: Gassée (2012) mentioned that with its Microsoft Exchange integration; a solid personal information manager that neatly combines mail, calendar, and contacts; and the secure BlackBerry Messenger network, the "CrackBerry" is rightly perceived as the best smartphone on the market. The success blinded the management and it refuses to accept that the iPhone poses a threat to their dominance. Apple and Google deploy technically superior software platforms that expose the BlackBerry's weaker underpinnings. In 2010, RIM acquires the QNX operating system in an effort to rebuild its software foundations, but it's too late.

Story is the same for Nokia. In 2007 Nokia was the world's largest mobile phone maker, but Nokia could not see the technical shortcomings of aging Symbian, or the utility of their attempts to "mobilize" Linux. It allows iOS and Android devices quickly eat into Nokia's market share and market cap.

(iii) Leadership: Ahonen (2013) listed the achievement of Elop, CEO of Nokia on three parameters, i.e., (i) Nokia revenue, Nokia profits, Standard \& Poor Ratings of Nokia, (ii) handset revenue, profits, volumes, market share, and (iii) smart phone unit revenue, profits, volumes, market share. He concluded that Nokia was $50 \%$ bigger than Samsung when Elop joined \& now Samsung is $30 \%$ bigger than Nokia in handset market. In smartphone segment Nokia was 
twice of number (2) Tim and Number (3) Apple and now even Samsung is 12 times of Nokia. He rated him as worst CEO. Similar sentiments were shown by Edwards (2013) in the context of "Burning Platform" memo.

(iv) Delay in giving up Symbian: Nokia was slow to react on the aging features of Symbian which were not in line of consumer demands (CHANG, 2012; $\mathrm{CIOL}, 2012)$. Microsoft is still shipping the $2^{\text {nd }}$ version of its Windows Phone OS, whereas Android and Apple are in their $10^{\text {th }}$ version (Jelly Bean) and $7^{\text {th }}$ version (iOS7) of Operating Systems (PATHAK, 2013).

(v) Politics of Middle Management: Middle management of any organization plays a crucial role in sustaining the growth in all segments. However, Nokia middle management was highly publicized. It was focusing more on internal competition and their personal interest. The phenomenon of co-operation was missing at middle level (DOMINIES COMMUNICATE, 2013).

(vi) Stiff Project Management: Exceedingly stiff project management model and management was another reason for lack of innovation and in turn downfall. Project management model was tuned to manufacturing process efficiency not for innovation. For the workforce it was difficult to innovate against the manufacturing process efficiency (DOMINIES COMMUNICATE, 2013).

(vii) Nokia failed in the race with Samsung: Nokia could not market itself as innovator in the market (CHANG, 2012; ClOL, 2012). The price of Nokia phones has been higher than Samsung phones. In addition, Samsung has the capacity to launch new models in every 40 days while Nokia has very limited capacity of introducing new models (FUNDEY.COM, 2012).

(viii) Hurt on the lower end and also by local vendors: Nokia did not anticipated competition in the lower end of the market. Its competitors such as HTC, Huawei and ZTE, competed better in low-end emerging markets like China (CHANG, 2102). Similarly, in dual SIM emerging market of India where in Nokia could not compete with local vendors such Micromax, Haier, Spice Mobiles, Maxx Mobiles etc; due to its arrogance (LOBO, 2011). The story was a repeat of dual SIM card phones in other countries such as Russia. Nokia was slow to react (MURTAZIN, 2011). 
(ix) Android paid off (for Samsung) and Windows Phone Hasn't ... Yet (for Nokia): Samsung bet on multiple platforms (Android, Windows Phone, and homegrown OS, Bada). Android paid off handsomely. Samsung chose Android at the right time. Nokia, spent time on Symbian. Its partnership with Microsoft was too late from business perspective (CHANG, 2012).

(x) Strategic Move in relation to MeeGo, Qt-A, Meltemi: Rox (2012) analyzed the strategies of the Nokia before February, 2011 and after arrival of Elop \& concluded that "bad luck + bad execution of plans and mistakes of Elop (CEO Nokia) lead to the massive downfall. Utkarsh (2013) cited MeeGo as NoGo, a reason for the downfall of Nokia. He also cited that Ovi store never really took off. Linux based Melteni platform melted due to layoff of employees by Nokia. However, it continued to make investment in Qt-A.

\section{GENERAL COMMENTS / VIEWS/ STATEMENTS OF THE EXPERTS / RESEARCHERS}

In the past experts, executives, researchers have expressed their views about the deal. They have described it as terrible idea to an excellent one in the context of economic environment across the globe. These views are listed in the following:

(i) Data given in table 1 is an ample proof that this deal is not very costly in comparison to earlier ones. Nokia bought NAVTEQ for 8.1 billion, which is the forefather of today's HERE Maps. It is included in Microsoft Nokia deal for 7.2 billion. It is therefore cheap acquisition.

(ii) Microsoft/Nokia deal is a terrible idea in the present context (MIMS, 2013).

(iii) There is very little in this acquisition for the Microsoft. Microsoft's, previous partnership with Nokia had yielded every bit of this deal as mentioned by Mobile Analyst Ben Thompson (MIMS, 2013).

(iv) It is an act of "quiet desperation" that is unlikely to succeed (Om Malik of GigaOm (MIMS, 2013)).

(v) It will drive volumes of business for Microsoft in mobile phone business domain CEO Microsoft (MIMS, 2013).

(vi) It will triple Window Phone Market Share by 2018 in many markets across the globe (BLAGDON, 2013). 
(vii) The layoff factor will be nil to nonexistent, as per Colliers International Senior Vice President Jim Beeger (DONATO-WEINSTEIN, 2013). It is contrary to Google-Motorola deal wherein layoff of $20 \%$ employees was announced as first step by Google after inking the deal (MILLER, 2012). The process of layoff by Google is continued during 2013 (ROWINSKI, 2013).

(viii) The deal that make no sense (THOMPSON, 2013).

(ix) Nokia buy makes it easier to envision cleaving Microsoft along devices and services lines of its business (FOLEY, 2013).

(x) Nokia threat: Microsoft had to buy Nokia because Nokia was going to stop making Windows Phones very soon and planning to switch to Android (Views of the experts (GRALLA, 2013).

(xi) It is a clear sign that Microsoft believes it can and must succeed in the phone business. It cannot afford to leave the success in the hands of a partner like Nokia. Microsoft's phone software has managed to pass BlackBerry, but remains a distant No. 3 platform to Google's Android and Apple's iOS (FRIED, 2013).

(xii) "It is combination of two weak companies. It will emerge as a strong new competitor in the phone domain is doubtful" said Paul Budde, a telecommunications consultant in Sydney. Further comments: "Both Nokia and Microsoft really missed the boat in terms of smartphones, and it is extremely difficult to claw your way back from that." (BASS; HEISKANEN; FICKLING, 2013).

(xiii) Metz (2013) reported that it will be a best shot to Microsoft in a world that's quickly moving from desktops and laptops (Microsoft's traditional domain) onto smartphones and tablets. Rise of Google's Android mobile operating system and the Apple iPhone, forced Microsoft to change its ways.

(xiv) Metz (2013) mentioned that Google bought Motorola, to better compete with Apple. Microsoft has bought Nokia to compete with both of them (Google \& Apple). He also said that Microsoft is in habit of following Google \& Apple.

(xv) Three lessons for Nokia (a) Nokia should have not rested on its laurels, (b) Nokia should have challenged itself, and (iii) Nokia should have been 
surrounded by Web companies or consumer-electronics manufacturers to succeed (LYNN, 2010). These lessons are true for today's winners also.

(xvi) On the capabilities of Window phone, a Senior Manager, Nokia Multimedia in T\&T forum said that "You can't make a Ferrari sports model on top of Lada engine" (DOMINIES COMMUNICATE, 2013).

(xvii) Nokia has strong carrier relationship with African telecom operators. It has brand equity, and excellent supply chain. It has a good position in Africa's dumb and feature phone segments. Microsoft will make advantages of it in future (HARRIS, 2013).

(xviii) Garnry (2013) mentioned that "The job is not done for Nokia. In fact the struggle might continue, but today Nokia is the winner. Microsoft is no longer one obvious buyer of BlackBerry's mobile division" now.

(xix) Marek (2013) mentioned that "if history is any indication, it's clear that even when the strongest companies acquire weaker ones, it doesn't spell instantaneous success".

Table 1: Past Acquisition in \$ Billion in the Domain

\begin{tabular}{|l|l|l|l|}
\hline SN & Deal & Year & Amount \\
\hline 1 & Google buys Motorola Mobility & 2011 & 12.5 Billion \\
\hline 2 & Microsoft buys Skype & 2011 & 8.5 Billion \\
\hline 3 & Nokia buys NAVTEQ & 2007 & 8.1 Billion \\
\hline 4 & Microsoft-Nokia deal & 2013 & 7.2 Billion \\
\hline 5 & Nokia buys out Siemens out of NSN & 2013 & 2.2 Billion \\
\hline 6 & Sony buys out Ericsson & 2012 & 1.5 Billion \\
\hline 7 & NSN buys Motorola audio assets & 2011 & 1.2 Billion \\
\hline 8 & Microsoft buys Yammer & 2012 & 1.2 Billion \\
\hline 9 & Face book buys Instagram & 2012 & 1.0 Billion \\
\hline 10 & Nokia sells Vertu Source: Peter (2013), Hill (2012) & 0.26 Billion \\
\hline
\end{tabular}

\section{SIMILARITIES \& DISSIMILARITIES OF THE PAST \& BUSINESS MODELS}

Zeigler C. (2011) reported that Google dropped its "top five" Android partners to let them know that this Motorola acquisition was taking place. Microsoft has not done yet after making the announcement of acquiring Nokia. However, it is reported by the experts that it may be end to Window Phone Licenses (ROGOWSKY, 2013).

Google's primary goal was to shore up Android's shaky patent situation. Though it was not the exact case for Microsoft but Nokia buy out had increased the size of the basket of its patents. 
The smart device market has two basic business models as followed by Apple \& Google. Additional models are also visible in the market \& can be termed as Samsung Model or future Microsoft-Nokia Model. These models are listed as under:

(i) Apple Model: Apple has focused on a closed vertical integration model where the device value is high and is based on a combination of software and hardware, and the cost model reflects that value. In addition, the closed nature of the ecosystem extends the control and the overall price (and underlying costs).

Baker (2013) mentioned that Apple has approached the market from the customer end, choosing to own the OS, most of the service infrastructure, the distribution as a way to keep as much revenue within their ecosystem and deliver profits. It is further moving back into the supply chain, developing its own processors for example.

(ii) Google Model: Google model has as many devices as possible allow users to consume Google cloud services. It has opened up OS Android to a large set of device vendors, driving a market where the software has little to no cost and reflects lower product costs and prices. Though recently, it had acquired Motorola to have some intent of Apple Model.

(iii) Samsung Model: Baker (2013) said that Samsung is primarily supply chainbased business model. It is controlling much of the production of the components and it can better manage cost and supply. In addition, it rely on others partners to provide the front-end customer services such as support of distribution, software, Operating System, and services. Further, it is venturing in to these domains by having its own OS \& other tools but these tools are not yet very popular.

(iv) Microsoft Model: Microsoft business model will be somewhat similar to Apple and Samsung. Microsoft has an OS basket, and other tools such as Skype \& Lync that depend on open integration of smart device which none of the competitors have in the domain (EDHOLM, 2013). He added further, that Microsoft has been out-flanked for two of the cloud pillars, search and social. In addition, Microsoft has a reasonable position in the gaming pillar (Xbox Live) but it has minimal positions in entertainment (Netflix, Amazon Prime, 
MSOs). It means, Microsoft's strength is in communications and productivity apps (Office 365). Still it has gaps. Nokia is the beginning of strategy which has filled the gap in the hardware segment. It also needs the client business the way Samsung and Apple do. In Microsoft environment its client partners are suffering. Even Nokia is an example. Window OS has failed to bailout it. After filling the gaps Microsoft may emerge with a better business model.

\section{REASONS FOR MICROSOFT TO BUYOUT NOKIA}

The community of the experts came out with many reasons that are responsible for the deals between Microsoft and Nokia. These reasons are listed in the following.

(i) To compete better with Android and iOS \& also to take full control of its smartphone destiny (CRINGELY, 2013; ROGOWSKY, 2013).

(ii) To support Ballmer's (CEO Microsoft) new devices and services strategy for the Microsoft (CRINGELY, 2013).

(iii) The deal will bring 32,000 Nokia employees on board of Microsoft. It will transform Microsoft into a true multinational company with all the tax flexibility (CRINGELY, 2013).

(iv) Acquisition of a global brand and an effort to keep Nokia away from jumping into the Android camp (CRINGELY, 2013).

(v) To create a setup which gives Nokia full control over the Windows Phone platform, and Microsoft does not want to lose its primacy over its mobile efforts (WILHELM, 2013).

(vi) Apple and Google control mobile software and hardware, which allows them to push their own services to users. Microsoft can do the same by acquiring Nokia phone business (WILHELM, 2013).

(vii) It is a mile stone in Microsoft's efforts to break Apple and Google's hold on smartphone business (WILLIAMS, 2013).

(viii) The deal will protect Windows Phone platform future and will make it may make it more competitive \& can give impetus to innovation (BARRETT, 2013; OVIDE, 2013). 
DOI: 10.14807/ijmp.v5i3.166

(ix) Microsoft currently makes less than $\$ 10$ from every Windows Phone unit sold; that number may go up when it's all in-house (BARRETT, 2013).

(x) Nokia's Lumia smartphones are beautiful, well-designed, solid, and top build quality. Lumia didn't sell well, but still more successful than Microsoft's Surface tablet. Nokia Lumia will guarantee that Microsoft's push into smartphones is not an embarrassment (BARRETT, 2013).

(xi) The deal provided an opportunity for better Utilization of cash Microsoft kept away from the US taxman (TIMMONS, 2013).

(xii) Finland is planning to cut its corporate tax rate to $20 \%$ from $24.5 \%$ to attract new business. It will be to the advantage of Microsoft (TIMMONS, 2013).

(xiii) Ballmer Statement "Integration of two great teams will accelerate Microsoft's share and profits in phones, and strengthen the overall opportunities for both Microsoft and our partners across our entire family of devices and services". It mean new synergies will be created (METZ, 2013).

(xiv) Google also bought an enormous collection of smartphone-related patents (more than 17000 patents at the total buy of $\$ 12.5$ billion in Motorola deal in Motorola deal). Microsoft does the same with Nokia deal by buying 8,500 design patents of Nokia (METZ, 2013; MILLER, 2102).

(xv) It will help Microsoft to make more money per handset, less redundant marketing efforts and access to the source code for Nokia's mapping software. But if App Ecosystem is not improved by Microsoft it will be a naught (JOHNSON, 2013).

(xvi) Microsoft was very keen to be in the Windows Phone smartphone business \& also wants to bring Stephen Elop back to the company as CEO (WOLF, 2013).

(xvii) It is possible that Nokia threatened to switch to Android (the relevant contracts are getting close to renewal), rather as Motorola threatened to sue other Android OEMs before Google bought it (GRALLA, 2013).

(xviii) Issues Related to Window Phone OS: Restrictions on Lumia 1020 camera software. A Bluetooth file sharing feature is particularly popular in developing 
countries, but Microsoft wasn't aware as US consumers don't typically use it. It can exploit these features in developing countries (WORSTALL, 2013).

\section{IMPACT OF THE BUYOUT ON STAKEHOLDERS OF ECOSYSTEM}

As reported by large number of experts of the industry, the deal will have a huge impact on the ecosystem of the mobile phone industry across the globe. It may put breaks on Android to convert present Unipolar OS market (as evident from the data given in tables A1 to A6) in to Multi-polar OS Market. Additional impacts of the deal are listed in the following.

(i) Shares of Microsoft slid as much as $6 \%$ in the afternoon of the deal date, reducing market value of Microsoft by $\$ 15$ billion, as investors protested the acquisition of an underperforming and marginalized corporation that lost more than $\$ 4$ billion in 2012 (REUTERS, 2013). It is in sync with synergy trap hypothesis in the context of mergers and acquisitions (MYEONG-CHEOL, et al. 2002).

(ii) It will brings an end to Nokia's three-decades-long adventure mobile phones selling, as well as speculation about a future sale to Redmond, dating back to the moment Nokia announced a former Microsoft executive, Stephen Elop, would take the reins in September 2010 (OLSON, 2013).

(iii) The deal will make Microsoft a big time hardware player, and Nokia will shift focus to technologies and software (RAJAN, 2013). Nokia will focus on its three established businesses, i.e., (a) network infrastructure and services; (b) mapping and location services; and (c) advanced technologies (RAJAN, 2013).

(iv) It will position Microsoft as number three provider in the smartphone domain (ROGOWSKY, 2013).

(v) It will effectively end the Windows Phone licensing business. It may not be true. Business model of Microsoft may emerge more innovative (ROGOWSKY, 2013).

(vi) It's a bold step into the future - a win-win for employees, shareholders and consumers of both companies (ASSOCIATED PRESS, 2013). 
(vii) It will expand the range of applications on Microsoft products. It may also force the competitors as well as Microsoft to innovate more in all segments of the mobile phone business.

(viii) Nokia shares jumped as much as 48 percent in Helsinki as the deal with Microsoft removes a money-losing handset business and lets Nokia focus on higher-margin networking gear (BASS; HEISKANEN; FICKLING, 2013). It is again in sync with synergy trap hypothesis in the context of mergers and acquisitions (MYEONG-CHEOL, et al. 2002).

(ix) Windows phone partners such as HTC, Samsung and Huawei will be loser (MIMS, 2013). It is yet to be proved.

(x) Asha OS: Microsoft has bought Nokia's line of Asha quasi-smart phones. These devices are halfway in between "dumb phones" and smartphones in features and processing power. Nokia has done an impressive job of making them into an affordable alternatives to smartphones for emerging markets. It may be end for Asha OS if it is replaced with Windows (MIMS, 2013).

(xi) Blackberry can no longer count on a Microsoft acquisition to save it (MIMS, 2013).

(xii) Samsung just recently pulled ahead of Nokia in India, and if Microsoft bungles the transition of India's Asha fans to Windows Phone, a transition that might not work even under the best circumstances. It will be an advantage to Samsung (MIMS, 2013).

(xiii) Huawei, ZTE and Samsung are already leading the Android charge in emerging markets, but right on their heels are the "no-name" manufacturers of Android phones, which already produce 1 in 4 Android handsets. If Asha is out of the race in India, the local manufacturers could make further inroads into a huge new market (MIMS, 2013).

(xiv) The acquisition may solve Nokia's problem of cash (GRALLA, 2013).

(xv) It had prevented the only Windows Phone original equipment manufacturer (OEM) from vanishing from the market (GRALLA, 2013). 
(xvi) Microsoft would obviously reduce or remove the high charges for licensing its mobile operating system. Hence there is a possibility of getting low-priced Lumia phones very soon (DATTA, 2013).

(xvii) OEMs may develop their own 'non-Google' version of the Android OS, and may become independent of existing OS developers (PATHAK, 2013).

(xviii) Both Microsoft and BlackBerry will be competing for the third place in the war of operating systems specifically in the enterprise space (PATHAK, 2013).

(xix) Nokia's mobile telephony patents (10,000 in number) may put a little more financial strain on Korean Handset Manufacturers (Samsung, LG Electronics, and Pantech) (BUSINESS KOREA, 2013).

(xx) Nokia focus was on Asian Markets. Microsoft will focus on USA \& Europe Markets (SINGH, 2013). Microsoft may also focus on Asian markets.

(xxi) It may result in to breakup of Microsoft into at least two separate operating businesses: one focused on consumers and one on enterprises (WOLF, 2013).

(xxii) Microsoft will not lay off employees of Nokia. It will be ethical practice and may enhance job satisfaction among employees. It is in line with the theories of Lin and Wei (2006).

\section{CONCLUDING REMARKS}

The world is short of business models in the domain of smartphone business. It is battle of the supremacy between manufacturers of the handsets versus mobile operating system providers. Though the world of mobile OS is divided between Google, Apple, and Microsoft, but it is now between Android V/s rest OS providers. This is evident from the data given in table $A 1, A 3$ and $A 4$. This is the reason author termed Mobile OS world as a unipolar world. At the moment mobile operating system providers have upper hand over handset manufacturers. Hall (2013) mentioned that Microsoft has acquired Nokia "to accelerate its share and profits in phones, to create a first-rate Microsoft phone experience for its users, to prevent Google and Apple from foreclosing app innovation, integration, distribution and economics".

Many initiatives are taken by Nokia similar to the competitors. To mention, Samsung has branded Android products around Galaxy. In response, Nokia also 
tried to use Lumia. Rebranding of "Nokia Maps" to "HERE Maps" on non-Symbian platforms makes a total sense because map side of Nokia is free to expand in other markets (LITCHFIELD, 2013). It has been reported that Nokia's execution has been shoddy in recent years; it doesn't mean it can't make a comeback with Windows Phone. Nokia and Microsoft have huge assets. It may come out to be a good chemistry \& Windows Phone may be a great success. Even, Nokia's Mobile Telephony Patents may put a Strain on Korean Handset Manufacturers.

Microsoft may bring in to the market powerful combination of low-cost, secure, functional smartphones. It may integrate across multiple devices e.g. smartphones, PCs and game console, that can meet the requirement of individual and businesses users. Microsoft can incorporate Yammer, Skype, Xbox, Outlook and Office to compete with Google Android. Recent entry of new operating system players like Ubuntu, Firefox and Tizen will make war of smartphone operating systems very interesting in days to come. In addition, growth of small local vendors will provide a good competition to Microsoft. To mention, two local vendors such as Micromax, Karbonn in India are competing with international brands as can be seen from the data given in Table A5 \& Table A6.

The bigger issues with Microsoft could be integration of the employees of Nokia as well as phone business, competing with Google, be a device company or a services company. It is not like Google at the moment as Microsoft is not removing Nokia employees from jobs. It is in line with findings of Lin and Wei (2006). Buyout also proves the synergy trap hypothesis of Myeong-Cheol Park, et al. (2002). For other two hypothesis data is not yet generated by the merger.

In the end, it is summarized that present Mobile OS world is "Unipolar" world as far as mobile operating system is concerned. Still the ecosystem will consist of many Mobile OS players which will compete successfully with Android, and all categories of mobile phones manufacturers due to economic conditions of the users in different parts of the world. It will include international, national, as well as local brands. This conclusion is somewhat in line of conclusion of Singh and Nayeem (2011) in case of expansion strategies of biggies in Business Intelligence domain. 


\section{REFERENCES}

AHONEN, T. T. (2013). The Do-It-Yourself Elop Analysis. Access: September 06, 2013, Available from: http://communities-dominate.blogs.com/brands/2013/09/thedo-it-yourself-elop-analysis.html.

\section{ASSOCIATED PRESS (2013), Nokia stock surges on Microsoft takeover.}

Access: September 4, 2013, Available from:

http://gadgets.ndtv.com/mobiles/news/nokia-shares-jump-40-percent-after-microsoftdeal-413750?fb.

BAKER, S. (2013). Microsoft and Nokia signal a new era. Access: September 09, 2013, Available from: https://www.npdgroupblog.com/microsoft-and-nokia-mergersignals-a-new-era/\#.Ui383H9u_Dc.

BARRETT, B. (2103). Why Microsoft Bought Nokia (And What It Means for You). Access: September 06, 2013, Available from: http://gizmodo.com/why-microsoftbought-nokia-and-what-it-means-for-you-1244653272.

BASS D.; HEISKANEN V.; FICKLING D. (2013), Microsoft to Buy Nokia's Devices Unit for \$7.2 Billion. Access: September 4, 2013, Available from:

http://www.bbc.co.uk/news/business-23940171.

\section{BLAGDON, J. (2103). With Nokia, Microsoft wants to triple Windows Phone} market share by 2018. Access: September 07, 2013, Available from:

http://www.theverge.com/2013/9/3/4688962/with-nokia-microsoft-wants-to-triplewindows-phone-marketshare-by-2018/in/4453001.

BUSINESS KOREA (2013). What Impact Will It Have on Korean Smartphone Manufacturers. Access: September 04, 2013, Available from:

http://www.businesskorea.co.kr/article/1396/microsoft\%E2\%80\%99s-buyout-nokiawhat-impact-will-it-have-korean-smartphone-manufacturers.

CHANG, A. (2012). 5 reasons why Nokia lost its handset sales lead and got downgraded to "Junk". Access: September 09, 2013, Available from:

http://www.wired.com/gadgetlab/2012/04/5-reasons-why-nokia-lost-its-handsetsales-lead-and-got-downgraded-to-junk/.

CIOL (2012), Three reasons why Nokia failed. Access: September 9, 2013, Available from: http://www.ciol.com/ciol/news/103721/three-reasons-nokia-failed.

CLOODT, M.; HAGEDOORN, J.; KRANENBURG, H. V. (2006). Mergers and acquisitions: Their effect on the innovative performance of companies in high-tech industries, Research Policy, n. 35, p. 642-654.

CRINGELY, R. X. (2013). Why Microsoft really bought Nokia. Access: on September 06, 2013, Available from: http://betanews.com/2013/09/05/why-microsoftreally-bought-nokia/.

DATTA, S. (2103). Will Microsoft's Acquisition Affect The Smartphone Market In India?. Access: September 09, 2013, Available from:

http://www.dqindia.com/dataquest/analysis/194768/will-microsofts-acquisition-affectthe-smartphone-market-in-india.

DOMINIES COMMUNICATE (2013), Nokia: The rise and fall of a giant. Access: September 9, 2013, Available from: 
http://dominiescommunicate.wordpress.com/2013/02/06/nokia-the-rise-and-fall-of-agiant/.

DONATO-WEINSTEIN, N. (2013). Microsoft + Nokia deal impact on Valley CRE? Probably not much: Expert. Access: September 07, 2013, Available from:

http://www.bizjournals.com/sanjose/news/2013/09/03/microsoft-nokia-deal-impacton.html

EDHOLM, P. (2103). Microsoft and Nokia: After a Few Days' Reflection. Access: September 07, 2013, Available from:

http://www.nojitter.com/post/240160902/microsoft-and-nokia-after-a-few-daysreflection.

EDWARDS, J. (2013). All Microsoft Employees Should Read Stephen Elop's

'Burning Platform' Memo Right Now. Access: September 03, 2013, Available from: http://www.businessinsider.com/stephen-elops-burning-platform-memo-2013-9.

FOLEY, M. J. (2013). Does its Nokia buy thwart or fuel a possible Microsoft break-up?. Access: September 07, 2013, Available from:

http://www.zdnet.com/does-its-nokia-buy-thwart-or-fuel-a-possible-microsoft-breakup-7000020158/.

FRIED I. (2013), Microsoft to Buy Nokia's Device Business in Deal Worth \$7.17 Billion. Access: September 4, 2013, Available from:

http://allthingsd.com/20130902/microsoft-to-buy-nokias-device-business-for-7-17billion-euros/.

FUNDEY.COM (2012), Reasons of decline of Nokia: A critical analysis of its downfall. Access: September 9, 2013, Available from:

http://fundey.com/2012/10/why-did-nokia-decline-causes-of-nokia-downfall/

GARNRY, P. (2013). Microsoft-Nokia Deal: What Does It Mean For BlackBerry?.

Access: September 13, 2013, Available from:

http://gulfbusiness.com/2013/09/microsoft-nokia-deal-what-does-it-mean-forblackberry/\#.UjMw2X9u_Dc

GASSÉE, J. (2012). Will Microsoft buy RIM or Nokia?. Access: September 03, 2013, Available from: http://www.theguardian.com/technology/2012/jan/19/mondaynote-microsoft-nokia-rim

GRALLA, P. (2013). Did Nokia blackmail Microsoft into a sale by threatening to abandon Windows Phone?. Access: September 07, 2013, Available from: http://blogs.computerworld.com/windows-phone/22748/did-nokia-blackmailmicrosoft-sale-threatening-abandon-windows-phone

HALL, B. S. (2013). Windows phone \& Android Hate. Access: September 09, 2013, Available from: http://techpinions.com/windows-phone-android-andhate/22730.

HARRIS, L. (2013). Nokia deal could help Microsoft curb Google threat in

Africa. Access: September 13, 2013, Available from: http://www.zdnet.com/nokiadeal-could-help-microsoft-curb-google-threat-in-africa-7000020469/.

HILL, K. (2012). 10 Reasons Why Face book Bought Instagram. Access: October 16, 2013, Available from: http://www.forbes.com/sites/kashmirhill/2012/04/11/tenreasons-why-facebook-bought-instagram/. 
JOHNSON, D. (2013). Why the Microsoft-Nokia merger is doomed. Access:

September 11, 2013, Available from: http://www.cbsnews.com/8301-505143_16257601912/why-the-microsoft-nokia-merger-is-doomed/.

LITCHFIELD, S. (2013). The Microsoft buy-out: is there an impact on the Symbian world?. Access: September 10, 2013, Available from: http://www.allaboutsymbian.com/features/item/18302_The_Microsoft_buyout_is_there.php.

LIN, C.; YU-CHEN WEI (2006). The Role of Business Ethics in Merger and Acquisition Success: An Empirical Study, Journal of Business Ethics, v. 69, n. 1, p. $95-109$

LOBO, S. (2011). Arrogance, the reason for Nokia's downfall. Access: September 9, 2013, Available from: http://www.cxotoday.com/story/nokia-microsoft-deal/

LYNN, M. (2010). Nokia's Downfall Holds Three Lessons for Europe: Matthew Lynn. Access: September 09, 2013, Available from:

http://www.bloomberg.com/news/2010-09-13/nokia-s-decline-holds-three-lessonsfor-europe-commentary-by-matthew-lynn.html.

MAREK, S. (2013). How does Microsoft's $\$ 7.2$ billion purchase of Nokia stack up to other similar deals?. Access: September 23, 2013, Available from:

http://www.fiercewireless.com/story/how-does-microsofts-72-billion-purchase-nokiastack-other-similar-deals/2013-09-03.

METZ, C. (2013), With \$7.17 Billion Nokia Buy, Microsoft Brings Its Trojan Horse Home. Access: September 6, 2013, Available from: http://www.wired.com/business/2013/09/microsoft-nokia/.

MILLER, C.C. (2012). Motorola Set for Big Cuts as Google Reinvents It. Access: September 07, 2013, Available from:

http://www.nytimes.com/2012/08/13/technology/motorola-to-cut-20-of-work-forcepart-of-sweeping-change.html?pagewanted=all\&_r=1\&.

MIMS, C. (2013). Who wins and who loses in Microsoft's acquisition of Nokia. Access: on September 07, Available from: http://qz.com/120817/who-wins-and-wholoses-in-microsofts-acquisition-of-nokia/.

MURTAZIN, E. (2010). Dual SIM phone market. Access: September 09, 2013, Available from: http://mobile-review.com/articles/2010/dual-sim-phone-marketen.shtml.

MYEONG-CHEOL, P.; DONG-HOON, Y.; CHANGI, N.; YOUNG-WOOK, H. (2002). Mergers and Acquisitions in the Telecommunications Industry: Myths and Reality, ETRI Journal, v. 24, n. 1, p. 56-64.

OLSON, P. (2013), Microsoft To Buy Nokia's Mobile Business For \$5B, License Patents For \$2.2B. Access: September 4, 2013, Available from:

http://www.forbes.com/sites/parmyolson/2013/09/03/microsoft-to-buy-nokias-mobilebusiness-for-5b-license-patents-for-2-2b/.

OVIDE, S. (2013), Deal is easy part for Microsoft and Nokia. Access: September 04, 2013, Available from:

http://online.wsj.com/article/SB10001424127887324432404579052112731349626.ht $\mathrm{ml}$. 
PATHAK, T. (2013). Microsoft buy-out of Nokia: Impact on various elements of the Mobile phone ecosystem. Access: September 10, 2013, Available from: http://cmrindia.com/microsoft-buy-out-of-nokia-impact-on-various-elements-of-themobile-phone-ecosystem/.

PETER (2013). Is Microsoft buying Nokia too cheaply? Here's how the deal scales against other recent acquisitions in tech. Access: September 11, 2013, Available from: http://blog.gsmarena.com/microsoft-nokia-deal-scaled-against-otherrecent-acquisitions-in-tech/.

RAJAN, N. (2013), Microsoft to buy Nokia handset business for 5.44 bn euros, bring home Lumia. Access: September 4, 2013, Available from:

http://businesstoday.intoday.in/story/microsoft-to-buy-nokia-devices-business-bringshome-lumia/1/198282.html.

RANGER, S. (2103). Microsoft's Windows Phone overtakes BlackBerry, but Android dominates smartphones utterly. Access: September 09, 2013, Available from: http://www.zdnet.com/microsofts-windows-phone-overtakes-blackberry-butandroid-dominates-smartphones-utterly-7000019381/.

REDMOND (2013), Microsoft to acquire Nokia's devices \& services business, license Nokia's patents and mapping services. Access: September 4, 2013, Available from: http://www.microsoft.com/en-us/news/press/2013/Sep13/0902AnnouncementPR.aspx.

REUTERS (2013), Microsoft swallows Nokia's phone business for $\$ \mathbf{7 . 2}$ billion. Access: September 4, 2013, Available from:

http://in.reuters.com/article/2013/09/03/microsoft-nokia-idINDEE98202R20130903.

ROGOWSKY, M. (2013), Microsoft Wants To Outdo Google And Apple, Buying Nokia Helps With Neither. Access: September 6, 2013, Available from: http://www.forbes.com/sites/markrogowsky/2013/09/03/microsoft-wants-to-outdogoogle-and-apple-buying-nokia-helps-with-neither/.

ROWINSKI, D. (2013). More Rubble: Google Dismisses 1,200 More Motorola Employees. Access: on December 23, 2013, Available from:

http://readwrite.com/2013/03/08/more-rubble-google-dismisses-1-200-moremotorola-employees\#awesm= os5yPOYIhQRFRZ.

ROX, U. (2012), Why and how did Nokia fall and who should be held responsible for it?. Access: September 9, 2013, Available from: http://symbiandevelopers.net/the-downfall-of-nokia/.

SINGH, N. P.; NAYEEM, Z. (2011). Critical Analysis of Expansion Strategies of SAP, IBM, Oracle and Microsoft in the area of Business Intelligence, International Journal of Strategic Information Technology and Applications, v. 2, n. 2, p. 2343. 
SINGH, R. (2013). It's now Microsoft v/s Micromax. The Economic Times, Magazine Corporate, September 08-14, p. 16-18.

THOMPSON, B. (2013). BlackBerry - and Nokia's - Fundamental Failing, August, 12. Access: September 01, 2013, Available from:

http://stratechery.com/2013/blackberry-and-nokias-fundamental-failing/.

THOMPSON, B. (2013). The deal that makes no sense. Access: September 07, 2013, Available from: http://stratechery.com/2013/the-deal-that-makes-no-sense/.

TIMMONS, H. (2013). Microsoft is funding its Nokia acquisition with cash it kept from the taxman. Access: September 06, 2013, Available from:

http://qz.com/120616/microsoft-is-funding-its-nokia-acquisition-with-cash-it-keptfrom-the-taxman/.

UTKARSH (2013), The downfall of Nokia - 11 reasons why they are doing so badly. Access: September 9, 2013, Available from: http://utkarshmits.blogspot.in/2013/01/the-downfall-of-nokia-11-reasons-why_561.html.

WALTON, Z. (2013). Microsoft Explains The Rationale Behind Its Nokia

Purchase. Access: September 07, 2013, Available from:

http://www.webpronews.com/microsoft-explains-the-rationale-behind-its-nokiapurchase-2013-09?utm_source=Business_sidebar.

WILHELM, A. (2013). Why Microsoft Had No Choice But To Purchase Nokia's Handset Business. Access: September 06, 2013, Available from:

http://techcrunch.com/2013/09/03/why-microsoft-had-no-choice-but-to-purchasenokias-handset-business/.

WILLIAMS, C. (2013). Microsoft buys Nokia mobile business to challenge

Apple and Google. Access: September 6, 2013, Available from:

http://www.telegraph.co.uk/technology/microsoft/10283087/Microsoft-buys-Nokiamobile-business-to-challenge-Apple-and-Google.html.

WOLF, M. (2013). Will Buying Nokia Lead to the Breakup of Microsoft?. Access:

September 11, 2013, Available from: http://finance.yahoo.com/blogs/the-

exchange/buying-nokia-lead-breakup-microsoft-170655561.html.

WORSTALL, T. (2013). The Real Reason Microsoft Bought Nokia. Transaction

Costs. Access: September 10, 2013, Available from:

http://www.forbes.com/sites/timworstall/2013/09/08/the-real-reason-microsoftbought-nokia-transaction-costs/.

ZEIGLER, C. (2011). Google buying Motorola: Nokia, Samsung, and other industry players react. Access: September 6, 2013, Available from:

http://www.theverge.com/2011/08/15/google-motorola-nokia-samsung-androidacquisition/. 


\section{ANNEXURE}

Table A1: Top Smartphone Operating Systems, Shipments, and Market Share, 2013

Q3 (Units in Millions)

\begin{tabular}{|l|l|l|l|l|l|}
\hline $\begin{array}{l}\text { Operating } \\
\text { System }\end{array}$ & $\begin{array}{l}\mathbf{2 Q 1 3} \text { Unit } \\
\text { Shipments }\end{array}$ & $\begin{array}{l}\mathbf{2 Q 1 3} \text { Market } \\
\text { Share \% }\end{array}$ & $\begin{array}{l}\mathbf{2 Q 1 2} \text { Unit } \\
\text { Shipments }\end{array}$ & $\begin{array}{l}\mathbf{2 Q 1 2} \\
\text { Market } \\
\text { Share \% }\end{array}$ & $\begin{array}{l}\text { Year-Over- } \\
\text { Year Change } \\
\text { \% }\end{array}$ \\
\hline Android & 187.4 & 79.3 & 108 & 69.1 & 73.5 \\
\hline iOS & 31.2 & 13.2 & 26 & 16.6 & 20.0 \\
\hline $\begin{array}{l}\text { Windows } \\
\text { Phone }\end{array}$ & 8.7 & 3.7 & 4.9 & 3.1 & 77.6 \\
\hline Blackberry OS & 6.8 & 2. & 7.7 & 4.9 & -11.7 \\
\hline Linux & 1.8 & 0.8 & 2.8 & 1.8 & -35.7 \\
\hline Symbian & 0.5 & 0.2 & 6.5 & 4.2 & -92.3 \\
\hline Others & $\mathrm{N} / \mathrm{A}$ & 0.0 & 0.3 & 0.3 & -100.0 \\
\hline Total & 236.4 & 100 & 156.2 & 100. & 51.3 \\
\hline & & & & & \\
\hline
\end{tabular}

Continued...

Source: IDC Worldwide Mobile Tracker, August 07, 2013

\begin{tabular}{|c|c|c|c|c|}
\hline Operating System & $\begin{array}{ll}\text { 2Q11 } & \text { Unit } \\
\text { Shipments }\end{array}$ & \begin{tabular}{|l|} 
2Q11 \\
Share \%
\end{tabular} & $\begin{array}{ll}\text { 2Q10 } & \text { Unit } \\
\text { Shipments }\end{array}$ & $\begin{array}{l}\text { 2Q10 Market } \\
\text { Share \% }\end{array}$ \\
\hline Android & 50.8 & 46.97 & 20.5 & 25.5 \\
\hline iOS & 20.4 & 18.8 & 13.5 & 16.7 \\
\hline Windows Phone & 2.5 & 2.3 & 2.2 & 2.8 \\
\hline Blackberry OS & 12.5 & 11.5 & 11.9 & 14.8 \\
\hline Linux & 3.3 & 3.0 & 1.7 & 2.1 \\
\hline Symbian & 18.3 & 16.9 & 29.5 & 36.6 \\
\hline Others & 0.6 & 0.5 & 1.2 & 1.5 \\
\hline Total & 108.3 & 100 & 80.5 & 100 \\
\hline
\end{tabular}

Source: For 2010: http://tamss60.tamoggemon.com/2010/11/14/gartner-on-smartphone-marketshare-q3-2010/ Continued...

\begin{tabular}{|l|l|l|l|l|l|}
\hline $\begin{array}{l}\text { Operating } \\
\text { System }\end{array}$ & $\begin{array}{l}\text { 2Q09 Unit } \\
\text { Shipments }\end{array}$ & $\begin{array}{l}\text { 2Q09 Market } \\
\text { Share (\%) }\end{array}$ & $\begin{array}{l}\text { 2Q08 Unit } \\
\text { Shipments }\end{array}$ & $\begin{array}{l}\text { 2Q08 Market } \\
\text { Share (\%) }\end{array}$ & $\begin{array}{l}\text { Year-Over- } \\
\text { Year Change } \\
(\%)\end{array}$ \\
\hline Android & 1.2 & 2.8 & - & - & - \\
\hline iOS & 5.2 & 13.7 & 0.7 & 2.1 & 626.9 \\
\hline $\begin{array}{l}\text { Windows } \\
\text { Phone }\end{array}$ & 3.4 & 9.0 & 4.8 & 14.3 & -28.7 \\
\hline Blackberry OS & 8.0 & 20.9 & 5.6 & 16.7 & 41.6 \\
\hline Symbian & 19.2 & 50.3 & 19.6 & 58.2 & -2.1 \\
\hline Others & 1.2 & 3.3 & 2.9 & 8.6 & -56.8 \\
\hline Total & 38.1 & 100 & 33.6 & 100 & 100 \\
\hline & & & & & \\
\hline
\end{tabular}

Source: http://radar.oreilly.com/2009/08/whos-winning-the-smartphone-wa.html 
Table A2: Worldwide Mobile Terminal Sales to End Users in 3Q10 (Thousands of Units)

\begin{tabular}{|c|c|c|c|c|c|c|}
\hline Company & Q3 2009 & $\begin{array}{l}\text { Q3 Share } \\
\text { in } \%\end{array}$ & Q3 2010 & $\begin{array}{l}\text { Q3 Share } \\
\text { in } \%\end{array}$ & Q3 2011 & $\begin{array}{l}\text { Q3 } 2011 \\
\text { Share in } \\
\%\end{array}$ \\
\hline Nokia & $113,466.20$ & 36.7 & $117,461.00$ & 28.2 & $82,612.20$ & 18.7 \\
\hline Samsung & $60,627.70$ & 19.6 & $71,671.80$ & 17.2 & $105,353.50$ & 23.9 \\
\hline LG & $31,901.40$ & 10.3 & $27,478.70$ & 6.6 & $17,295.30$ & 3.9 \\
\hline Apple & $7,040.40$ & 2.3 & $13,484.40$ & 3.2 & $14,107.80$ & 3.2 \\
\hline $\begin{array}{l}\text { Research In } \\
\text { Motion }\end{array}$ & $8,522.70$ & 2.8 & $11,908.30$ & 2.9 & $21,014.60$ & 4.8 \\
\hline Sony Ericsson & $13,409.50$ & 4.3 & $10,346.50$ & 2.5 & $10,668.20$ & 2.4 \\
\hline Motorola & $13,912.80$ & 4.5 & $8,961.40$ & 2.1 & $9,004.70$ & 2 \\
\hline HTC & $2,659.50$ & 0.9 & $6,494.30$ & 1.6 & $12,701.10$ & 2.9 \\
\hline ZTE & $4,143.70$ & 1.3 & $6,003.60$ & 1.4 & $11,182.70$ & 2.5 \\
\hline $\begin{array}{l}\text { Huawei } \\
\text { Technologies }\end{array}$ & $3,339.70$ & 1.1 & $5,478.10$ & 1.3 & $12,099.90$ & 2.7 \\
\hline Others & $49,871.10$ & 16 & $137,797.60$ & 33 & $145,462.20$ & 32.9 \\
\hline Total & $308,894.70$ & 100 & $417,085.70$ & 100 & $441,502.20$ & 100 \\
\hline
\end{tabular}

2009, 2010: http://www.gartner.com/newsroom/id/1466313 2011: http://www.gartner.com/newsroom/id/2237315

Continued...

\begin{tabular}{|c|c|c|c|c|}
\hline & & & & \\
\hline Company & Q3 2012 & $\begin{array}{l}\text { Q3 } 2012 \text { Share } \\
\text { in \% }\end{array}$ & Q2 2013 & $\begin{array}{l}\text { Q2 } 2013 \text { Share } \\
\text { in \% }\end{array}$ \\
\hline Samsung & $97,956.80$ & 22.9 & $107,526.0$ & 24.7 \\
\hline Nokia & $82,300.60$ & 19.2 & $60,953.7$ & 14.0 \\
\hline Apple & $23,550.30$ & 5.5 & $31,899.7$ & 7.3 \\
\hline ZTE & $16,654.20$ & 3.9 & 15.280 .7 & 3.5 \\
\hline LG Electronics & $13,968.80$ & 3.3 & $17,016.4$ & 3.9 \\
\hline Huawei Device & $11,918.90$ & 2.8 & $11,275.1$ & 2.6 \\
\hline TCL Communication & $9,326.70$ & 2.2 & $10,134.3$ & 2.3 \\
\hline Research in Motion & $8,946.80$ & 2.1 & - & - \\
\hline Motorola & $8,562.70$ & 2 & - & - \\
\hline HTC & $8,428.60$ & 2 & - & - \\
\hline Others & $146,115.10$ & 34.2 & $181,072.5$ & 41.7 \\
\hline Total & $427,729.50$ & 100 & $435,158.4$ & 100 \\
\hline
\end{tabular}

Source: 2012: http://www.gartner.com/newsroom/id/2237315

2013: http://www.gartner.com/newsroom/id/2573415 
Table A3: Smart Phone OS Sales (\%) in Select Countries

\begin{tabular}{|c|c|c|c|c|c|c|c|}
\hline Germany & $\begin{array}{l}3 \mathrm{~m} / \mathrm{e} \\
\text { July } \\
2012\end{array}$ & $\begin{array}{l}3 \mathrm{~m} / \mathrm{e} \\
\text { July } \\
2013\end{array}$ & $\begin{array}{l}\% \\
\text { Change }\end{array}$ & USA & $\begin{array}{l}3 \mathrm{~m} / \mathrm{e} \\
\text { July } \\
2012\end{array}$ & $\begin{array}{l}3 \mathrm{~m} / \mathrm{e} \\
\text { July } \\
2013\end{array}$ & $\begin{array}{l}\% \\
\text { Change }\end{array}$ \\
\hline iOS & 13.3 & 11.2 & -2.1 & iOS & 35.6 & 43.4 & 7.8 \\
\hline Android & 73.3 & 76.8 & 3.4 & Android & 58.7 & 51.1 & -7.6 \\
\hline BlackBerry & 0.6 & 0.8 & -0.2 & BlackBerry & 1.9 & 1.2 & -0.7 \\
\hline Symbian & 5.0 & 1.4 & -3.6 & Symbian & 0.0 & 0.0 & 0.0 \\
\hline Windows & 6.2 & 8.8 & 2.6 & Windows & 3.0 & 3.5 & 0.5 \\
\hline Others & 1.5 & 1.0 & -0.5 & Others & 0.9 & 0.8 & -0.1 \\
\hline GB & $\begin{array}{l}3 \mathrm{~m} / \mathrm{e} \\
\text { July } \\
2012\end{array}$ & $\begin{array}{l}3 \mathrm{~m} / \mathrm{e} \\
\text { July } \\
2013\end{array}$ & $\begin{array}{l}\% \\
\text { Change }\end{array}$ & China & $\begin{array}{l}3 \mathrm{~m} / \mathrm{e} \\
\text { July } \\
2012\end{array}$ & $\begin{array}{l}3 \mathrm{~m} / \mathrm{e} \\
\text { July } \\
2013\end{array}$ & $\begin{array}{l}\% \\
\text { Change }\end{array}$ \\
\hline iOS & 23.3 & 31.1 & 7.8 & iOS & 26.3 & 22.4 & -3.9 \\
\hline Android & 59.1 & 55.2 & -3.8 & Android & 61.7 & 70.5 & 8.8 \\
\hline BlackBerry & 11.0 & 3.5 & -7.5 & BlackBerry & 0.1 & 0.1 & 0.0 \\
\hline Symbian & 1.7 & 0.5 & -1.2 & Symbian & 5.2 & 2.9 & -2.2 \\
\hline Windows & 4.2 & 9.2 & 5.0 & Windows & 4.6 & 2.4 & -2.2 \\
\hline Others & 0.7 & 0.4 & -0.3 & Others & 2.2 & 1.6 & -0.5 \\
\hline France & $\begin{array}{l}3 \mathrm{~m} / \mathrm{e} \\
\text { July } \\
2012\end{array}$ & $\begin{array}{l}3 \mathrm{~m} / \mathrm{e} \\
\text { July } \\
2013\end{array}$ & $\begin{array}{l}\% \\
\text { Change }\end{array}$ & Australia & $\begin{array}{l}3 \mathrm{~m} / \mathrm{e} \\
\text { July } \\
2012\end{array}$ & $\begin{array}{l}3 \mathrm{~m} / \mathrm{e} \\
\text { July } \\
2013\end{array}$ & $\begin{array}{l}\% \\
\text { Change }\end{array}$ \\
\hline iOS & 12.7 & 17.3 & 4.6 & iOS & 28.0 & 28.1 & 0.1 \\
\hline Android & 62.1 & 62.5 & 0.4 & Android & 62.9 & 62.0 & -0.9 \\
\hline BlackBerry & 9.2 & 3.7 & -5.5 & BlackBerry & 1.4 & 0.3 & -1.1 \\
\hline Symbian & 2.1 & 1.5 & -0.6 & Symbian & 1.8 & 1.1 & -0.7 \\
\hline Windows & 3.6 & 11.0 & 7.4 & Windows & 4.6 & 7.0 & 2.4 \\
\hline Others & 10.3 & 4.1 & -6.2 & Others & 1.3 & 1.4 & 0.4 \\
\hline Italy & $\begin{array}{l}3 \mathrm{~m} / \mathrm{e} \\
\text { July } \\
2012\end{array}$ & $\begin{array}{l}3 \mathrm{~m} / \mathrm{e} \\
\text { July } \\
2013\end{array}$ & $\begin{array}{l}\% \\
\text { Change }\end{array}$ & Mexico & $\begin{array}{l}3 \mathrm{~m} / \mathrm{e} \\
\text { July } \\
2012\end{array}$ & $\begin{array}{l}3 \mathrm{~m} / \mathrm{e} \\
\text { July } \\
2013\end{array}$ & $\begin{array}{l}\% \\
\text { Change }\end{array}$ \\
\hline iOS & 14.8 & 16.2 & 1.5 & iOS & 3.3 & 9.2 & 5.8 \\
\hline Android & 58.2 & 71.0 & 12.8 & Android & 28.3 & 60.0 & 31.7 \\
\hline BlackBerry & 4.1 & 1.8 & $\begin{array}{l}-1.2 \\
\end{array}$ & BlackBerry & 34.9 & 10.0 & -25.0 \\
\hline Symbian & 12.4 & 1.8 & -10.5 & Symbian & 24.7 & 7.3 & -17.5 \\
\hline Windows & 8.3 & 7.8 & -0.5 & Windows & 2.0 & 12.5 & 10.5 \\
\hline Others & 2.3 & 0.3 & -2.0 & Others & 6.7 & 1.1 & -5.6 \\
\hline Spain & $\begin{array}{l}3 \mathrm{~m} / \mathrm{e} \\
\text { July } \\
2012\end{array}$ & $\begin{array}{l}3 \mathrm{~m} / \mathrm{e} \\
\text { July } \\
2013\end{array}$ & $\begin{array}{l}\% \\
\text { Change }\end{array}$ & EUS & $\begin{array}{l}3 \mathrm{~m} / \mathrm{e} \\
\text { July } \\
2012\end{array}$ & $\begin{array}{l}3 \mathrm{~m} / \mathrm{e} \\
\text { July } \\
2013\end{array}$ & $\begin{array}{l}\text { \% } \\
\text { Change }\end{array}$ \\
\hline iOS & 2.9 & 6.1 & 3.1 & iOS & 14.8 & 17.9 & 3.1 \\
\hline Android & 82.5 & 89.9 & 7.3 & Android & 66.2 & 69.1 & 2.9 \\
\hline BlackBerry & 9.4 & 0.7 & -8.7 & BlackBerry & 6.7 & 2.4 & -4.3 \\
\hline Symbian & 2.1 & 0.7 & -1.5 & Symbian & 4.3 & 1.1 & -3.1 \\
\hline Windows & 1.7 & 1.8 & 0.1 & Windows & 4.9 & 8.2 & 3.3 \\
\hline Others & 1.4 & 0.9 & -0.5 & Others & 3.2 & 1.3 & -1.9 \\
\hline
\end{tabular}

Table A4: India Smartphone Share by Operating System

\begin{tabular}{|c|c|c|c|}
\hline Operating System & $\mathbf{2 0 1 2}$ & $\mathbf{2 0 1 7}$ & Source \\
\hline Android & $74 \%$ & $74 \%$ & Singh (2013) \\
\hline Window Phone & $4 \%$ & $15 \%$ & \\
\hline Apple iOS & $3 \%$ & $6 \%$ & \\
\hline Blackberry & $6 \%$ & $4 \%$ & \\
\hline Others & $14 \%$ & $1 \%$ & \\
\hline
\end{tabular}


Table A5: Market Share of Feature Phones

\begin{tabular}{|c|c|c|c|c|}
\hline Manufacturer & 2011 Q2 & 2012 Q2 & 2013 Q2 & Source \\
\hline Nokia & $23 \%$ & $17 \%$ & $15 \%$ & Singh (2013) \\
\hline Samsung & $14 \%$ & $17 \%$ & $12 \%$ & \\
\hline Karbonn & $5 \%$ & $5 \%$ & $8 \%$ & \\
\hline Micromax & $8 \%$ & $5 \%$ & $8 \%$ & \\
\hline Others & $50 \%$ & $56 \%$ & $57 \%$ & \\
\hline
\end{tabular}

Table A6: Smart Phone Market Share in India

\begin{tabular}{|c|c|c|c|c|}
\hline Manufacturer & $\mathbf{2 0 1 1} \mathbf{Q 2}$ & $\mathbf{2 0 1 2} \mathbf{Q 2}$ & $\mathbf{2 0 1 3} \mathbf{Q 2}$ & Source \\
\hline Nokia & $46 \%$ & $17 \%$ & $5 \%$ & Singh (2013) \\
\hline Samsung & $21 \%$ & $50 \%$ & $26 \%$ & \\
\hline Karbonn & $0 \%$ & $1 \%$ & $13 \%$ & \\
\hline Micromax & $1 \%$ & $6 \%$ & $22 \%$ & \\
\hline Others & $32 \%$ & $24 \%$ & $34 \%$ & \\
\hline
\end{tabular}

